\title{
Structure of the ichthyofauna of adventitious streams in the South Pantanal
}

\author{
Virginia S. Uieda' (1Dttp://orcid.org/0000-0002-6078-1342 \\ César Y. Fujihara² (1D http://orcid.org/0000-0002-1208-9060
}

\begin{abstract}
1. Departamento de Zoologia, Instituto de Biociências, UNESP - Universidade Estadual Paulista, Caixa Postal 510, 18618-970 Botucatu, SP, Brasil. (vsuieda@gmail.com) 2. Unidade Universitária de Coxim, Universidade Estadual de Mato Grosso do Sul, Rua General Mendes de Moraes, 370, Jardim Aeroporto, 79400-000, Coxim, MS, Brasil. (cyfujihara@gmail.com)
\end{abstract}

Received 8 July 2017

Accepted 15 April 2018

Published 11 June 2018

DOI 10.1590/1678-4766e2018019

ABSTRACT. The ichthyofauna of the Taquari River, one of the main tributaries of the South Pantanal, has been studied since the 1970s; however, there is a gap on the studies about the ichthyofauna present on the small adventitious streams of this highly dendritic system. These streams are small tributaries that flow directly into large rivers (mainstem), at least three orders greater in magnitude. The aim of this study was to analyze the structure of the ichthyofauna of five adventitious streams of the Upper Taquari River, South Pantanal, evaluating its temporal variation (dry and wet season) and the relation to the habitat characteristics and the conservation of the streams. Thirty-seven species were collected, from which 14 are exclusive to the Paraguay River basin, one species [Apteronotus albifrons (Linnaeus, 1766)] could represent a new record for this basin, and six species need taxonomic confirmation. The analysis indicated only the existence of spatial variation in the ichthyofauna structure of the streams sampled, with the similarity patterns related to the distance between the streams and to their conditions of conservation. The stream with greater size and preserved riparian forest was the one with the highest values of fish diversity and evenness. On the other hand, the stream with the smallest percentage of riparian forest and highest proximity to urban area presented the lowest diversity. The small size of these adventitious systems should serve as protection against large predators, which have their access to those areas hampered by their own size. Otherwise, the mainstem may also act as source of dispersal of small-bodied schooling fishes to the adventitious streams, where the greater heterogeneity of habitats and the presence of riparian vegetation should offer shelter and food supply for small species.

KEYWORDS. Lotic habitat, diversity, fish, Paraguay River basin, Upper Taquari River.

RESUMO. Estrutura da ictiofauna de riachos adventícios do Pantanal Sul. A ictiofauna do Rio Taquari, um dos principais afluentes do Pantanal Sul, foi estudada desde a década de 70; entretanto, há uma lacuna nos estudos sobre a ictiofauna presente nos pequenos rios adventícios deste sistema altamente dendrítico. Esses riachos são pequenos tributários que fluem diretamente para grandes rios, pelo menos três ordens maiores em magnitude. $\mathrm{O}$ objetivo do presente estudo foi analisar a estrutura da ictiofauna de cinco riachos adventícios do Alto Rio Taquari, Pantanal Sul, avaliando sua variação temporal (estação seca e chuvosa) e sua relação com as características do habitat e a conservação dos riachos. Foram coletadas 37 espécies, das quais 14 são de ocorrência exclusiva na bacia do Rio Paraguai, uma espécie [Apteronotus albifrons (Linnaeus, 1766)] pode representar uma nova ocorrência nessa bacia e seis espécies ainda necessitam de confirmação taxonômica. A análise indicou somente a existência de variação espacial na estrutura da ictiofauna dos riachos amostrados, com os padrões de similaridade relacionados à distância entre os riachos e às condições de conservação. O riacho com maior tamanho e com vegetação ripária bem preservada apresentou os maiores valores de diversidade e equitabilidade. Por outro lado, o riacho com o menor porcentual de cobertura vegetal e maior proximidade com a área urbana apresentou menor diversidade. O pequeno tamanho desses sistemas adventícios deve servir como proteção contra grandes predadores, que têm acesso a essas áreas prejudicadas por seu próprio tamanho. Por outro lado, o rio principal também pode atuar como fonte de dispersão de peixes de cardumes para os riachos adventícios, onde a maior heterogeneidade de habitats e a presença de mata ciliar devem oferecer abrigo e suprimento de alimento para espécies pequenas.

PALAVRAS-CHAVE. Ambientes lóticos, diversidade, peixes, bacia do Rio Paraguai, Alto Rio Taquari.

The distribution of the ichthyofauna in rivers with wetland can be analyzed in two distinct compartments, the plateau region with lotic environments and the floodplain region where the flood pulse exerts a strong influence on the ecological processes (WILlinK et al., 2000; GALDINO et al., 2006). In this complex integrated system, little emphasis has been placed on the study of adventitious streams or adjacent small rivers. Adventitious streams are small tributaries $\left(1^{\text {st }}\right.$ to $3^{\text {rd }}$ order) that flow directly into large rivers (mainstem) at least three orders greater in magnitude (GoRMAN, 1986). In these environments, species composition may vary according to watershed structure, species potential of migration and environmental conditions (HitT \& ANGERMEIER, 2006). Seasonally, adventitious streams may show more or less variation in their species composition according to the entry of migratory species (GORMAN, 1986), which inhabits the areas located further downstream (PAVANELLI \& CARAMASCHI, 2003; SchaefER \& Kerfoot, 2004). Thus, the interface 
between adventitious streams and the mainstem may present a fish assemblage diverse and variable over time (SCHAEFER \& KERFOOT, 2004) due to the connectivity of these stream types (THOMAS \& HaYes, 2006).

THOMAS \& HAYES (2006) examined the fish community and habitat structure of one fifth-order mainstem, two secondorder adventitious tributaries to the mainstem, and three second-order headwater streams and verified that fish species richness generally increased with increasing stream order and was similar but higher in the adventitious streams than in the headwater streams. Factors in addition to stream order, such as stream connectivity and temperature (THOMAs \& HAYES, 2006), stream environmental characteristics and stream channel location within a network (OSBORNE \& WILEY, 1992; Grenouillet et al., 2004; ThornBrugh \& Gido, 2010; Hitt \& ANGERMEIER, 2011) are also indicated as important determinants of stream fish assemblage in this type of drainage network.

The Taquari River is one of the main tributaries draining the South Pantanal. The ichthyofauna of this river has been studied since the 1970s, with the objective of improving knowledge for conservation and fisheries purposes of the Pantanal (CATELLa et al., 1996; WillinK et al., 2000; Resende \& SANTos, 2002; RotTA, 2003; Britski et al., 2007; Froenlich et al., 2017). However, there is a gap on the studies about the ichthyofauna present on the small adventitious streams of this highly dendritic system of the Upper Taquari River basin, represented by species dependent on the stream conditions of conservation, with potential occurrence of endemism, and that still needs more studies (Froehlich et al., 2017).

Thus, the present work aims to analyze and compare spatially and temporally the structure of the ichthyofauna of five adventitious streams of the Taquari River, evaluating its relation to the characteristics and conservation of the streams. The hypothesis is of a spatial difference in the structure of the ichthyofauna, with greater diversity in the streams with characteristics more stable temporally and in better state of environmental preservation.

The work also intends to contribute to the knowledge of the ichthyofaunal structure of adventitious streams, an important ecosystem of the central-western region of Brazil. As pointed out by WILLINK et al. (2000), the main threats to the fishes of the Pantanal area are due to human occupation, leading to the removal of riparian forest, which alters the habitat quality for the aquatic fauna.

\section{MATERIAL AND METHODS}

The study was carried out in five adventitious streams of the Upper Taquari River Basin (Fig. 1). The Taquari River is located on the left bank of the Upper Paraguay Basin, which, together with the Paraná and Uruguay Basins, forms the Prata Basin (Piedra-Cueva, 2009). In the area, the savanna with open arboreal vegetation and the pasture predominate (ANTAS \& NASCIMENTO, 1996; BRASIL, 1997). The climatic regime is characterized by a dry season in the
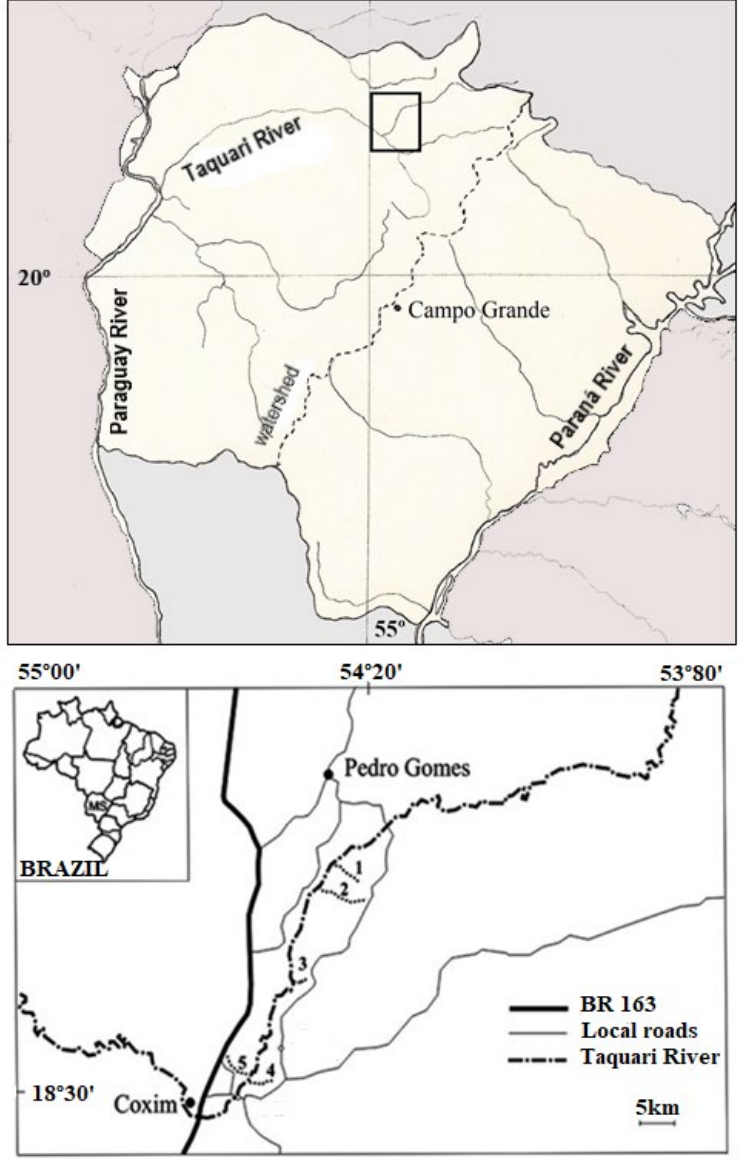

Fig. 1. Location of Mato Grosso do Sul state in Brazil (MS), the state being delimited by the Paraguay River to the west, with the studied area in the Taquari River indicated by a rectangle (map above) and amplified to indicate the location of the studied streams (map below) (Streams: 1, Óleo; 2, Cabeceira Comprida; 3, Firmino; 4, Toni; 5, Aldeia).

middle of the year that can last from 3 to 4 months and a rainy season at the end and beginning of each year (IBGE, 1990).

The five adventitious streams studied comprised three of first order and two of second order, characterized by small dimensions and extension, moderate current, predominantly sandy-clay substrate and presence of riparian vegetation (Tab. I). However, some differences between the streams can be emphasized, such as rocky substrate in Toni stream, less shading in Aldeia stream, and higher values of extension, width, depth, current and discharge in Cabeceira Comprida and Aldeia streams. The Toni stream was also the one that presented the highest values for most limnologic variables analyzed (Tab. I).

The fish were sampled two times in the dry season (June and August 2007) and two in the wet season (December 2007 and February 2008) (Collection license IMASUL/MS, $n^{\circ} 23 / 100605 / 2008$ ). In each stream, a stretch of 75 meters was selected, located at a distance of 0.4 to $1.8 \mathrm{~km}$ from the mouth on the Taquari River (Tab. I) with the aim of minimizing the effect of floods near the mainstem. The selected sample sections present typical characteristics of small-order streams $\left(1^{\text {st }}\right.$ and $2^{\text {nd }}$ order), with a good representation of pool-runriffle mesohabitats. 
Tab. I. Characterization of the five adventitious streams of the Taquari River basin, Brazil being presented the mean and standard deviation of the variables measured during four months of sampling (June, August and December 2007; February 2008). Total extension and distance of the sample section from the mouth at the Taquari River were estimated from an IBGE cartographic map 1:100.000 (Firmino stream was not registered).

\begin{tabular}{|c|c|c|c|c|c|}
\hline Variables & Óleo & C. Comprida & Firmino & Toni & Aldeia \\
\hline Channel order & $1^{\text {st }}$ & $2^{\text {nd }}$ & $1^{\mathrm{st}}$ & $2^{\text {nd }}$ & $1^{\mathrm{st}}$ \\
\hline Extension (km) & 5.5 & 10.0 & - & 4.0 & 6.0 \\
\hline Distance $(\mathrm{km})$ & 0.7 & 1.1 & 0.4 & 1.8 & 1.2 \\
\hline Substrate & Sandy-clay & Sandy-clay & Sandy-clay & Rocky & Sandy \\
\hline Degree of shading $(\%)$ & $95.1 \pm 1.2$ & $98.5 \pm 0.6$ & $99.0 \pm 1.2$ & $87.7 \pm 2.8$ & $54.3 \pm 5.5$ \\
\hline Width (m) & $1.7 \pm 0.1$ & $2.4 \pm 0.2$ & $1.4 \pm 0.1$ & $2.0 \pm 0.2$ & $2.5 \pm 0.5$ \\
\hline Depth $(\mathrm{cm})$ & $5.6 \pm 1.0$ & $13.4 \pm 1.9$ & $4.6 \pm 0.8$ & $5.6 \pm 0.9$ & $11.8 \pm 2.1$ \\
\hline Current (m/s) & $0.33 \pm 0.03$ & $0.44 \pm 0.09$ & $0.31 \pm 0.06$ & $0.09 \pm 0.09$ & $0.47 \pm 0.15$ \\
\hline Discharge $\left(\mathrm{m}^{3} / \mathrm{s}\right)$ & $0.034 \pm 0.09$ & $0.158 \pm 0.089$ & $0.020 \pm 0.008$ & $0.002 \pm 0.004$ & $0.199 \pm 0.095$ \\
\hline Dissolved oxygen $(\mathrm{mg} / \mathrm{l})$ & $9.6 \pm 1.0$ & $9.4 \pm 0.8$ & $9.1 \pm 0.4$ & $5.9 \pm 2.5$ & $9.1 \pm 0.8$ \\
\hline Conductivity $(\mu \mathrm{S} / \mathrm{cm})$ & $16.5 \pm 2.2$ & $22.0 \pm 5.1$ & $10.7 \pm 0.9$ & $268.6 \pm 23.2$ & $5.3 \pm 1.3$ \\
\hline Alkalinity (mg/l) & $11.1 \pm 0.3$ & $14.6 \pm 2.7$ & $6.9 \pm 0.6$ & $34.6 \pm 14.2$ & $4.0 \pm 0.4$ \\
\hline Hardness (mg/l) & $3.4 \pm 0.5$ & $7.0 \pm 2.8$ & $3.9 \pm 0.6$ & $87.1 \pm 56.9$ & $1.4 \pm 0.8$ \\
\hline $\mathrm{pH}$ & $6.8 \pm 0.1$ & $7.1 \pm 0.1$ & $6.7 \pm 0.1$ & $6.8 \pm 0.2$ & $5.9 \pm 0.1$ \\
\hline Total phosphorus $(\mu \mathrm{g} / \mathrm{l})$ & $19.8 \pm 6.8$ & $40.5 \pm 33.8$ & $29.8 \pm 15.5$ & $20.9 \pm 12.2$ & $12.6 \pm 4.3$ \\
\hline Total nitrogen $(\mu \mathrm{g} / \mathrm{l})$ & $116.2 \pm 32.4$ & $136.4 \pm 117.3$ & $108.5 \pm 122.2$ & $237.5 \pm 104.9$ & $67.8 \pm 103.0$ \\
\hline
\end{tabular}

The fish were sampled using seine ( 4.5 meters long) and sieve $(0.8 \times 0.6 \mathrm{~m})$, both made with a $2.5 \times 1 \mathrm{~mm}$ mesh size. The 75 meters stretch was divided into 15 areas of 5 meters each, repeating the sampling methodology described below in the 15 areas, from downstream to upstream direction. Two collectors maintained the seine downstream of the area while, five meters above, two other collectors walked kicking the substrate until the seine, which was carefully lifted and inspected. After this procedure, and with the seine reinstalled at the same site, two collectors used the sieve on the marginal vegetation, and then lifted and inspected the net again. The specimens captured were preserved on ice in the field and, in the laboratory, were fixed in 10\% formaldehyde. After one week, the specimens were transferred and stored in $70 \%$ alcohol. The fish were identified (BRITSKI et al., 2007) and specimens of all species were deposited at the Museu de Zoologia da Universidade de São Paulo (MZUSP 103723 to 103857 ).

The absolute abundance data was analyzed for fish assemblage differences between streams (spatial) and seasons (temporal), using the statistical package Primer version 6.1.12 \& Permanova + version 1.0.2.

The abundance data of all replicates (two months per season in each of the five streams) was $\log (\mathrm{x}+1)$ transformed and used to construct a matrix of similarity (Bray-Curtis coefficient), for which the Non-Metric Multidimensional Scaling (NMDS) ordination technique was applied. The vectors of the species that presented total relative abundance above $5 \%$ were projected on the ordination. The quality of NMDS adjustment was obtained through the stress measure, considered ideal when the stress value is less than or equal to $10 \%$ (KINDT \& CoE, 2005). Using the same matrix of similarity, a Permutation Multivariate Analysis of Variance (PERMANOVA) and a Permutation Multivariate Dispersion (PERMDISP) were used to test for spatial and seasonal differences and for the interaction between both factors (ANDERSON et al., 2008). A significant value of PERMANOVA $(p<0.01)$ indicates that there are disparities between the groups, but this difference can be determined by the factor analyzed or by the dispersion of data. Thus, to understand the origin of this difference, it should be applied a PERMDISP, where a non-significant value $(p>0.01)$ indicates that the differences are due to the analyzed factor, in which case a pairwise test is applied.

The Shannon-Wiener diversity (H', base 2) and the Simpson Evenness (E 1/D) indices were calculated from the abundance data of the fish species (KREBS, 1999). The significance of spatial and seasonal differences on the diversity indices was verified using a $t$ test (ZAR, 1974).

Species dominance curves were constructed by stream and season, with species ranked in decreasing order of abundance and $\mathrm{x}$-axis on a log scale (BROWER \& ZAR, 1984).

\section{RESULTS}

In the five studied adventitious streams, 37 species were collected, belonging to 17 families (Tab. II). The orders Characiformes ( 5 families, 15 species), Siluriformes (5 families, 12 species) and Gymnotiformes (4 families, 6 species) presented the greatest number of families and species, with the first two orders representing $73 \%$ of the total species captured. The orders Cyprinodontiformes (1 family, 1 species), Synbranchiformes (1 family, 1 species) and Perciformes (1 family, 2 species) were the ones less represented in the streams.

From the 37 species sampled, only five presented a relative total abundance higher than $5 \%$, with the predominance of Characidium $\mathbf{c f}$. zebra and Hyphessobrycon herbertaxelrodi (Tab. III). The similarity analysis between streams and seasons, considering the fish abundance data of the four replicates (two per season in each stream), showed mainly spatial patterns. The NMDS ordination applied 
Tab. II. Fish species sampled in five adventitious streams of Taquari River basin, Brazil and their occurrence in the Paraguay (PY) and Upper Paraná (PA) sub-basins, according to the checklist presented by FroEHLICH et al. (2017) (+, present; -, absent; ?, specific name not determined).

\begin{tabular}{|c|c|c|c|}
\hline Family & Species & PY & PA \\
\hline \multirow[t]{10}{*}{ Characidae } & Astyanax abramis (Jenyns, 1842) & + & - \\
\hline & Astyanax asuncionensis Géry, 1972 & + & - \\
\hline & Astyanax lineatus (Perugia, 1891) & + & - \\
\hline & Astyanax marionae Eigenmann, 1911 & + & - \\
\hline & Bryconamericus exodon Eigenmann, 1907 & + & + \\
\hline & Hyphessobrycon herbertaxelrodi Géry, 1961 & + & + \\
\hline & Jupiaba acanthogaster (Eigenmann, 1911) & + & - \\
\hline & Moenkhausia sanctaefilomenae (Steindachner, 1907) & + & + \\
\hline & Piabarchus analis (Eigenmann, 1914) & + & - \\
\hline & Serrapinnus kriegi (Schindler, 1937) & + & - \\
\hline Crenuchidae & Characidium cf. zebra Eigenmann, 1909 & + & + \\
\hline \multirow[t]{2}{*}{ Erythrinidae } & Hoplerythrinus unitaeniatus (Spix \& Agassiz, 1829) & + & + \\
\hline & Hoplias malabaricus (Bloch, 1794) & + & + \\
\hline Lebiasinidae & Pyrrhulina australis Eigenmann \& Kennedy, 1903 & + & + \\
\hline Parodontidae & Parodon nasus Kner, 1859 & + & + \\
\hline \multirow[t]{3}{*}{ Gymnotidae } & Gymnotus pantanal Fernandes et al., 2005 & + & - \\
\hline & Gymnotus paraguensis Albert \& Crampton, 2003 & + & + \\
\hline & Gymnotus sp. Linnaeus, 1758 & $?$ & $?$ \\
\hline Hypopomidae & Brachyhypopomus sp. & $?$ & $?$ \\
\hline Sternopygidae & Sternopygus macrurus (Bloch \& Schneider, 1801) & + & + \\
\hline Auchenipteridae & Tatia neivai (Ihering, 1930) & + & + \\
\hline \multirow[t]{2}{*}{ Callichthyidae } & Callichthys callichthys (Linnaeus, 1758) & + & + \\
\hline & Corydoras aeneus (Gill, 1858) & + & + \\
\hline \multirow[t]{3}{*}{ Heptapteridae } & Imparfinis stictonotus (Fowler, 1940) & + & - \\
\hline & Phenacorhamdia hoehnei (Miranda Ribeiro, 1914) & + & - \\
\hline & Rhamdia quelen (Quoy \& Gaimard, 1824) & + & + \\
\hline \multirow[t]{4}{*}{ Loricariidae } & Ancistrus sp. Kner, 1854 & $?$ & $?$ \\
\hline & Hypostomus sp. 1 & $?$ & $?$ \\
\hline & Hypostomus sp. 2 & $?$ & $?$ \\
\hline & Hypostomus sp. 3 & $?$ & $?$ \\
\hline Trichomycteridae & Ituglanis eichorniarum (Miranda Ribeiro, 1912) & + & - \\
\hline Rivulidae & Melanorivulus punctatus (Boulenger, 1895) & + & - \\
\hline Synbranchidae & Synbranchus marmoratus Bloch, 1795 & + & + \\
\hline \multirow[t]{2}{*}{ Cichlidae } & Aequidens plagiozonatus Kullander, 1984 & + & - \\
\hline & Crenicichla lepidota Heckel, 1840 & + & - \\
\hline
\end{tabular}

Tab. III. Absolute abundance of fish species sampled in five adventitious streams of Taquari River basin, Brazil during the dry (D) and wet season (W), and the percentage (\%) of the total abundance per species (Streams: O, Óleo; C, Cabeceira Comprida; F, Firmino; T, Toni; A, Aldeia).

\begin{tabular}{|c|c|c|c|c|c|c|c|c|c|c|c|}
\hline Species & OD & OW & $\mathrm{CD}$ & $\mathrm{CW}$ & FD & FW & TD & TW & $\mathrm{AD}$ & AW & $\%$ \\
\hline A. abramis & - & 4 & - & - & 1 & 2 & - & - & 1 & - & 0.45 \\
\hline A. asuncionensis & 19 & 8 & - & - & 6 & 6 & 21 & 2 & 7 & 34 & 5.81 \\
\hline A. lineatus & 20 & 3 & 1 & 1 & 5 & 1 & - & - & - & - & 1.75 \\
\hline A. marionae & - & - & - & - & 1 & 1 & - & - & - & - & 0.11 \\
\hline B. exodon & 8 & 86 & - & - & 6 & 46 & - & - & - & - & 8.24 \\
\hline H. herbertaxelrodi & - & - & - & - & - & - & 80 & - & 180 & 37 & 16.76 \\
\hline J. acanthogaster & - & - & 15 & 18 & - & - & 8 & - & 17 & 7 & 3.67 \\
\hline$P$. analis & 2 & 7 & - & - & 7 & - & - & - & - & - & 0.90 \\
\hline S. kriegi & 3 & - & - & - & - & - & - & - & - & - & 0.17 \\
\hline C. cf. zebra & 214 & 35 & 22 & 22 & 165 & 36 & 2 & - & - & - & 27.99 \\
\hline H. unitaeniatus & - & 1 & - & - & - & - & - & - & - & - & 0.06 \\
\hline H. malabaricus & - & - & - & - & - & - & 1 & 8 & 3 & 1 & 0.73 \\
\hline P. australis & - & - & - & - & 2 & 1 & 2 & - & 4 & - & 0.51 \\
\hline$P$. nasus & - & - & - & 1 & - & - & - & - & - & - & 0.06 \\
\hline G. pantanal & - & - & - & - & 1 & - & - & - & - & - & 0.06 \\
\hline G. paraguensis & - & - & - & - & 1 & - & - & - & - & - & 0.06 \\
\hline Gymnotus sp. & - & - & - & - & 1 & - & - & - & - & - & 0.06 \\
\hline Brachyhyроротиs sp. & - & - & 1 & 1 & - & - & 1 & - & - & - & 0.17 \\
\hline S. macrurus & 1 & - & - & - & - & - & - & - & - & - & 0.06 \\
\hline T. neivai & - & - & 12 & 9 & - & - & - & - & - & - & 1.19 \\
\hline C. callichthys & - & - & - & - & 1 & 4 & - & 8 & - & - & 0.73 \\
\hline
\end{tabular}


Tab. III. Cont.

\begin{tabular}{|c|c|c|c|c|c|c|c|c|c|c|c|}
\hline Species & OD & OW & $\mathrm{CD}$ & $\mathrm{CW}$ & FD & $\mathrm{FW}$ & TD & TW & $\mathrm{AD}$ & AW & $\%$ \\
\hline C. aeneus & 3 & 1 & 15 & 31 & - & - & - & - & - & - & 2.82 \\
\hline I. stictonotus & - & - & - & - & - & - & 18 & 5 & 46 & 3 & 4.06 \\
\hline P. hoehnei & - & 2 & 11 & 8 & - & - & - & - & - & - & 1.19 \\
\hline R. quelen & 7 & 2 & 10 & 10 & 27 & 24 & 1 & - & 3 & 1 & 4.80 \\
\hline Ancistrus sp. & 3 & - & 7 & 2 & - & - & - & - & - & - & 0.68 \\
\hline Hypostomus sp. 1 & 5 & 2 & 5 & 9 & 1 & 1 & - & - & - & - & 1.30 \\
\hline Hypostomus sp. 2 & 3 & 3 & 8 & 11 & 1 & 2 & - & 39 & - & - & 3.78 \\
\hline Hypostomus sp. 3 & 5 & 2 & - & 1 & 6 & 2 & - & - & - & - & 0.90 \\
\hline L. platymetopon & 1 & - & 8 & 7 & - & - & - & - & - & - & 0.90 \\
\hline I. eichorniarum & 4 & 2 & 18 & 15 & 48 & 51 & 1 & - & 6 & 4 & 8.41 \\
\hline M. punctatus & - & - & - & - & - & - & 2 & - & 3 & - & 0.28 \\
\hline S. marmoratus & - & 1 & 1 & - & - & 1 & - & 1 & - & - & 0.23 \\
\hline A. plagiozonatus & - & - & - & - & - & - & - & 8 & - & - & 0.45 \\
\hline C. lepidota & - & - & 2 & - & - & - & - & 1 & 1 & - & 0.23 \\
\hline Total abundance & 298 & 159 & 136 & 148 & 280 & 178 & 138 & 74 & 274 & 87 & \\
\hline
\end{tabular}

to those data (Fig. 2) showed a high similarity between Óleo and Firmino samples of both seasons, grouped by the predominance of B. exodon and C. cf. zebra (Tab. III). The Cabeceira Comprida samples of both seasons had in common mainly species with intermediate abundance, although presented also, with Firmino samples, the predominance of R. quelen and I. eichorniarum. The Toni and Aldeia stream samples showed a greater dispersion in the NMDS ordination, with only two replicates grouped by the highest abundance of Astyanax asuncionensis and four by the highest abundance of Hyphessobrycon herbertaxelrodi (Tab. III, Fig. 2).

The PERMANOVA analysis did not indicate significant difference for the factor season (pseudo- $\mathrm{F}=1.28$, $\mathrm{p}=0.258)$ and for the interaction between season and stream (pseudo- $\mathrm{F}=0.77, \mathrm{p}=0.724$ ). The difference occurred only between streams (pseudo-F $=4.46, p<0.001$ ) and the PERMDISP confirmed that this difference was determined by the factor analyzed and not by the dispersion of data (pseudo- $\mathrm{F}=6.06, \mathrm{p}=0.041$ ). The pair-wise test did not showed significant difference only between Óleo and Firmino stream and between Toni and Aldeia stream.

Higher values of richness and abundance in the dry season and higher values of diversity and evenness in the wet season were found for most streams, except for the Cabeceira Comprida stream where the inverse occurred (Tab. IV). The test applied to the diversity index data showed significant differences between the diversity values of the Cabeceira Comprida and the values of all other streams (at both seasons), the diversity values of Firmino stream wet season and the values of most stream/season, and a seasonal difference only for Firmino stream (Tab. V).

The species dominance curves (Fig. 3) reinforced patterns of spatial variation, such as high dominance in Óleo, Firmino and Aldeia stream, mainly in the dry season, and high evenness in the Cabeceira Comprida stream at both seasons.

\section{DISCUSSION}

The ichthyofauna of neotropical rivers is characterized by the predominance of species of the orders Characiformes and Siluriformes, with the families Characidae and

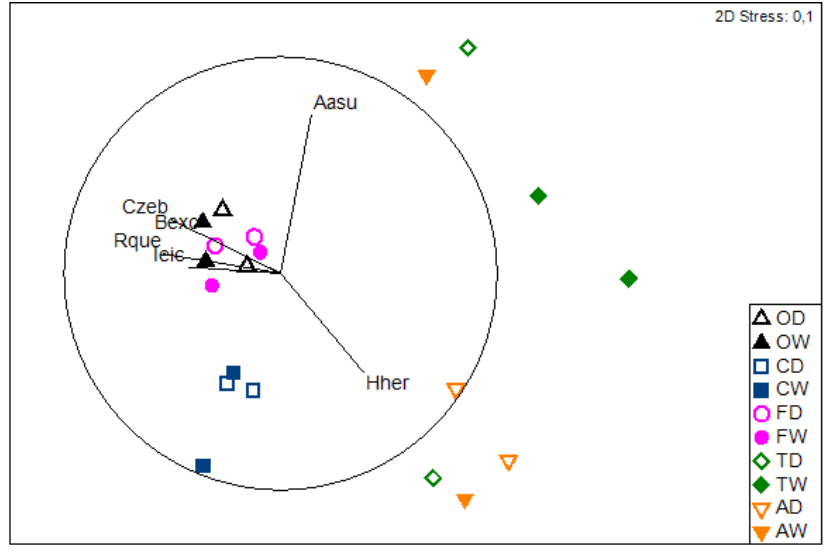

Fig. 2. Results of the ordination (NMDS) analysis applied to fish species (abundance data) sampled in five streams of the Taquari River basin, during the wet (W) and dry (D) season (two replicates per season). All species were used in the analysis but only species with more than $5 \%$ of total abundance were plotted in the graphic (Streams: O, Óleo; C, Cabeceira Comprida; F, Firmino; T, Toni; A, Aldeia. Species: Aasu, Astyanax asuncionensis; Bexo, Bryconamericus exodon; Czeb, Characidium cf. zebra; Hher, Hyphessobrycon herbertaxelrodi; Ieic, Ituglanis eichorniarum; Rque, Rhamdia quelen).

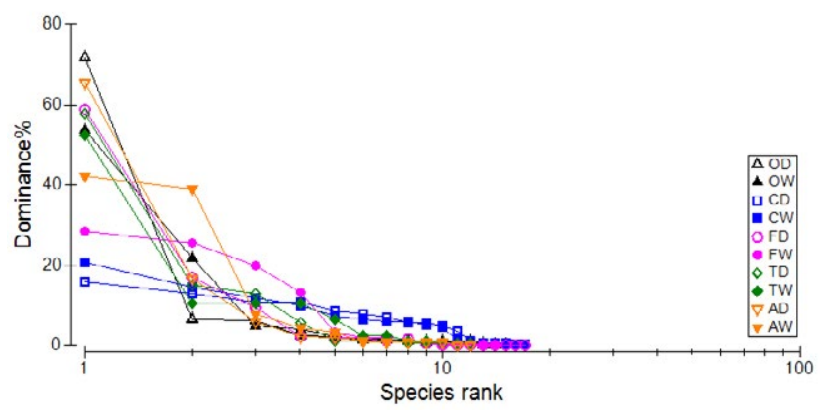

Fig. 3. Species dominance curves of the five streams of the Taquari River basin, constructed with the fish species abundance data on the dry (D) and wet season (W) (Streams: O, Óleo; C, Cabeceira Comprida; F, Firmino; T, Toni; A, Aldeia).

Loricariidae representing most species (REIS et al., 2003). This same structure was also described for the ichthyofauna of the aquatic ecosystems of the Pantanal area, located in Mato Grosso do Sul state (WiLlinK et al., 2000; FroeHLICH 
Tab. IV. Parameters calculated for the fish fauna sampled in five streams of Taquari River basin Brazil during the dry (D) and wet season (W).

\begin{tabular}{|c|c|c|c|c|c|c|c|c|c|c|}
\hline \multirow[b]{2}{*}{ Parameters } & \multicolumn{2}{|c|}{ Óleo } & \multicolumn{2}{|c|}{ C Comprida } & \multicolumn{2}{|c|}{ Firmino } & \multicolumn{2}{|c|}{ Toni } & \multicolumn{2}{|c|}{ Aldeia } \\
\hline & $\mathrm{D}$ & $\mathrm{W}$ & $\mathrm{D}$ & $\mathrm{W}$ & $\mathrm{D}$ & $\mathrm{W}$ & $\mathrm{D}$ & $\mathrm{W}$ & $\mathrm{D}$ & $\mathrm{W}$ \\
\hline Richness & 15 & 15 & 15 & 17 & 17 & 14 & 12 & 9 & 12 & 7 \\
\hline Total abundance & 298 & 159 & 136 & 148 & 280 & 178 & 138 & 76 & 274 & 87 \\
\hline Diversity (H') & 1.777 & 2.260 & 3.514 & 3.430 & 2.088 & 2.593 & 2.014 & 2.357 & 1.769 & 1.867 \\
\hline Eveness (E1/D) & 0.127 & 0.192 & 0.673 & 0.515 & 0.151 & 0.340 & 0.219 & 0.330 & 0.179 & 0.416 \\
\hline
\end{tabular}

Tab. V. Results of the diversity index comparison ( $\mathrm{t}$ test). * Values significantly different $(\alpha=0.05)$.

\begin{tabular}{|c|c|c|c|c|c|c|c|c|c|}
\hline & OW & OD & CW & $\mathrm{CD}$ & FW & FD & TW & TD & AW \\
\hline OD & 1.670 & - & - & - & - & - & - & - & - \\
\hline $\mathrm{CW}$ & $-5.304 *$ & $-6.795^{*}$ & - & - & - & - & - & - & - \\
\hline $\mathrm{CD}$ & $-6.000 *$ & $-7.462 *$ & -0.609 & - & - & - & - & - & - \\
\hline FW & -1.418 & $-3.185^{*}$ & $4.782 *$ & $5.750 *$ & - & - & - & - & - \\
\hline FD & 0.636 & -1.068 & $6.043 *$ & $6.772 *$ & $2.141^{*}$ & - & - & - & - \\
\hline TW & 0.084 & -1.747 & $6.353 *$ & $7.342 *$ & 1.733 & -0.621 & - & - & - \\
\hline $\mathrm{TD}$ & 0.956 & -0.854 & $6.919 *$ & $7.808^{*}$ & $2.634 *$ & 0.284 & 0.983 & - & - \\
\hline AW & 1.713 & -0.356 & $9.301 *$ & $10.796^{*}$ & $3.898 *$ & 0.955 & 1.885 & 0.686 & - \\
\hline $\mathrm{AD}$ & 1.840 & 0.030 & $7.673 *$ & $8.525^{*}$ & $3.570^{*}$ & 1.188 & 1.960 & 0.965 & 0.435 \\
\hline
\end{tabular}

et al., 2017), and for the adventitious streams of the Upper Taquari River studied here.

For the area of the Paraguay River basin, that drains the Pantanal and Plateau regions, BRITSKI et al. (2007) cited the occurrence of 269 fish species. For the same region, but covering only the state of Mato Grosso do Sul, FroeHLich et al. (2017) recorded 257 species, with all the species identified in the five adventitious streams studied here present in this list. Those species represent $14 \%$ of the total species listed by Froenlich et al. (2017), what emphasizes the need of more studies in the headwater streams of this area. Comparing the species sampled with the list presented by FroenLich et al. (2017), we find 14 of exclusive occurrence in the Paraguay River basin and 16 shared with the Paraná River basin.

The species Apteronotus albifrons could represent a new record for the Paraguay River basin list, but difficult to confirm since only one individual was collected. It was not possible to make the identification of one individual of Gymnotus and of three individuals of Brachyhypopomus, which if confirmed to be G. sylvius and B. gauderio could also be representing new records for the Paraguay River, as the presence of those two species was not indicated for this river basin by FroenLich et al. (2017).

For Ancistrus sp., although only A. cuiabae was included in the list of Paraguay River basin it is not possible to confirm that the 12 specimens sampled in two streams are this species because the troglobitic species A. formoso can also occur in headwaters of this basin (FrOEHLICH et al., 2017). For the genus Hypostomus, which had three species not identified in our work, there are still many systematic problems to investigate. As pointed out by FroEHLICH et al. (2017), the number of fish species on the list of Mato Grosso do Sul state is still incomplete, especially in the headwaters region, and much material already deposited in the scientific collections need identification and a more through revision, with some species still difficult to identify.
Characidium cf. zebra is described as a benthopelagic species, dominant in upper stretches of low-order streams characterized by sandy-rock substrate (FrOESE \& PAULY, 2010). The predominance of this species in the Óleo and Firmino streams could be related to their habitat characteristics, being both of $1^{\text {st }}$ order and with the smallest values of width and depth.

The low richness and the high dominance of $H$. herbertaxelrodi in Toni and Aldeia streams, mainly in the dry season, was determinant for the high similarity found between both. In Aldeia stream, the flow increase common in the wet season may be related to the reduction in the abundance of this species (about five times). Species of the genus Hyphessobrycon are common in sandy bottom Amazonian streams (BUHRNHEIM, 2002; ZuANON et al., 2006) and a lower abundance of $H$. aff. melazonatus have been reported in the wet season due to fish displacement to other areas during this period of high flow (BUHRNHEIM, 2002). For Toni stream, the occurrence of this species only during the dry season may be related to a temporary isolation of the sampled stretch, determined by a strong reduction of the flow at the end of the dry season and beginning of the wet season that happened during the study. Characidae specimens were found trapped in pools located above the stretch studied (CY Fujihara, personal communication).

The similarity between Aldeia and Toni stream can also be interpreted as a possible movement of fish between closer streams, using the Taquari River as a route for the displacement. The Taquari River presents a set of rapids and small waterfalls near the mouths of those streams, but maybe they do not form significant barriers for the species studied. Although not directly tested, the similarity patterns may be related to the distance between the streams and to the conservation conditions of the environments. Considering these two variables, the Aldeia and Toni streams are closer to each other and could be more subject to anthropic influence, as they are located closer to the city of Coxim. The highest 
values of conductivity, alkalinity, hardness and nitrogen found in Toni stream and the smallest value of riparian vegetation cover found in Aldeia stream corroborates this hypothesis of anthropic influence.

Although CASATTI et al. (2005) emphasized that some Hypostomus species are more generalist in respect to habitat occupation, foraging in diverse substrates and occurring in streams with or without riparian vegetation, this situation may not apply to the three species sampled in the adventitious streams. The occurrence of three non-determined species of Hypostomus in the four streams with high degree of shading, and their absence in the stream with the lowest vegetation cover, may be related to the preservation of the riparian vegetation. This vegetation is the main source of wood debris, that can provide substrate for peryphyton grow (ANGERMEIER \& KARR, 1984) and is the preferable microhabitat for some Hypostomus species that forage by scraping periphyton (UiEda et al., 1997; CASATTI, 2002).

The highest values of diversity found in the Cabeceira Comprida stream when compared to other streams can be related to its greater size, high values of depth and degree of shading. The highest values of evenness and the seasonal similarity in the species abundance can be indicative of the greater stability of this large stream, with small amount of riffles and well preserved riparian forest.

Although a low effect of seasonality over the structure of this fish assemblage occurred in the streams studied here, other works developed in adventitious streams found a seasonal variation. In some places it can be expected a seasonal variation in species richness and abundance, with a decrease during dry periods when the fish would temporarily relocate to the mainstem, or an increase at certain times each year when this place may be used for spawning by dwelling fish, as found by GORMAN (1986) in Indiana. In adventitious streams located in Michigan, Thomas \& HaYes (2006) also found a temporal richness variability, suggesting that some species moved between streams for life stage-specific habitat requirements. In two adventitious streams ( $2^{\text {nd }}$ and $3^{\text {rd }}$ order $)$ of the Paraná River, Pavanelli \& Caramaschi (2003) found that the ichthyofauna composition and distribution was influenced by the mainstem in a spatial and temporal scale, with an increase of migratory species and/or habitats diversity caused by the flood pulses. FLORES et al. (2009), studying the ichthyofauna of a tributary stream of the Paraná River, found seasonal variation only in the downstream region, attributing to the influence of the fish species of the Upper Paraná that probably use this region as a breeding area. Thus, as proposed by GoRMAn (1986), the influence of the seasonality upon the ichthyofaunal structure of adventitious streams seems to vary depending on the studied region because of differences in the mainstem assemblage.

In the adventitious streams studied here, the reduced depth probably prevented the entrance of medium size species (such as Schizodon borelli, Brycon hilarii and Salminus hilarii) and large size species (such as Prochilodus lineatus, Salminus brasiliensis, Piaractus mesopotamicus,
Pseudoplatistoma corruscans and $P$. fasciatum) that perform reproductive migrations in the Taquari River (RESENDE \& Santos, 2002). In the Paraguay River floodplain, Resende \& SANTOS (2002) reported that large size catfish predators attack schools of Prochilodus leaving lateral water bodies to move up the mainriver. In the Paraná River floodplain many piscivorous species of medium and large size present a broad spectrum of fish-preys, mainly small size characids (BozZa \& HaHn, 2010).

Thus, the small size of these adventitious systems should serve as a protection area against large predators, which have their access to those areas hampered by their own size. Otherwise, the mainstem may also act as source of dispersal of small-bodied schooling fishes to the adventitious streams, where the greater heterogeneity of habitats and the presence of riparian vegetation should offer shelter and food supply for small species. As the studies about the ichthyofaunal composition of this system are still poor developed, actions that can alter the flow of the river, such as the installation of small hydroelectric power stations, or that can promote deforestation, as human occupation and exploitation of the land, in areas that involves the headwaters need to be viewed with caution by the authorities.

Acknowledgements. To Osvaldo Takeshi Oyakawa (MZUSP, São Paulo) for the help on fish identification; to Adriana Maria Güntzel (UEMS, Universidade Estadual do Mato Grosso do Sul, Coxim), Eliana Aparecida Panarelli (UEMG, Universidade Estadual de Minas Gerais, Frutal) and Hamilton Antonio Rodrigues (UNESP, Universidade Estadual Paulista, Botucatu) for their assistance with the limnological analysis; to Mario Paiva for the fieldwork assistance; to FUNDECT for the scholarship granted to the second author.

\section{REFERENCES}

Anderson, M. J.; Gorley, R. N. \& Clarke, K. R. 2008. PERManova for PRIMER: guide to Software and Statistical Methods. Plymouth, Plymouth Marine Laboratory. 214p.

ANGermeIER, P. L. \& KARR, J. R. 1984. Relationships between woody debris and fish habitat in a small warmwater stream. Transactions of American Fisheries Society 113:716-726.

Antas, P. T. Z. \& Nascimento, I. L. S. 1996. Tuiuiú sob os céus do Pantanal. Biologia e conservação do tuiuiú Jabiru mycteria. São Paulo, Empresa das Artes. 175p.

BozzA, A. N. \& HaHN, N. S. 2010. Uso de recursos alimentares por peixes imaturos e adultos de espécies piscívoras em uma planície de inundação neotropical. Biota Neotropica 10(3):217-226.

BRASIL. 1997. Ministério do Meio Ambiente. Plano de conservação da Bacia do Alto Paraguai - PCBAP: diagnósticos dos meios físico e biótico. Meio Biótico. Brasília, PNMA. 433p.

Britski, H. A.; Silimon, K. Z. S. \& Lopes, B. S. 2007. Peixes do Pantanal. Manual de identificação. Brasília, Embrapa. 230p.

Brower, J. E. \& ZAR, J. A. 1984. Field and laboratory methods for general ecology. Iowa, W. C. Brown Publisher. 194p.

BuHrNheim, C. M. 2002. Heterogeneidade de habitats: rasos x fundos em assembleias de peixes de igarapés de terra firme na Amazônia Central. Revista Brasileira de Zoologia 19(3):889-905.

Casatti, L. 2002. Alimentação dos peixes em um riacho do Parque Estadual Morro do Diabo, bacia do Alto Rio Paraná, sudeste do Brasil. Biota Neotropica 2(2): http://www.biotaneotropica.org.br/v2n2/pt/ abstract?article+BN02502022002.

Casatti, L.; Rocha, F. C. \& Pereira, D. C. 2005. Habitat use by two species of Hypostomus (Pisces, Loricariidae) in Southeastern Brazilian 
streams. Biota Neotropica 5(2): http://www.biotaneotropica.org.br/ v5n2/pt/abstract?article+BN02905022005.

Catella, A. C.; Peixer, J. \& Palmeira, S. S. 1996. Sistema de controle da pesca de Mato Grosso do Sul. Maio/1994 a Abril/1995. Corumbá, EMBRAPA/CPAP. 49p.

FloRes, S.; ARAYA, P. R. \& HiRT, L. M. 2009. Fish diversity and community structure in a tributary stream of the Paraná River. Biological Limnology 21(1):57-66.

Froehlich, O.; Cavallaro, M.; Sabino, J.; Súarez, Y. R. \& Vilela, M. J. A. 2017. Checklist da ictiofauna do Estado de Mato Grosso do Sul, Brasil. Iheringia, Série Zoologia 107(supl.): e2017151.

Froese, R. \& Pauly, D. 2010. FishBase. World Wide Web electronic publication. Available at $<$ www.fishbase.org $>$. Accessed on 17 December 2010.

Galdino, S.; Vieira, L. M. \& Pellegrin, L. A. 2006. Impactos Ambientais e Socioeconômicos na Bacia do Rio Taquari - Pantanal. Corumbá, EMBRAPA/CPAP. 356p.

GoRmAn, O. T. 1986. Assemblage organization of stream fishes: the effect of rivers on adventitious streams. The American Naturalist 128(4):611616.

Grenouillet, G.; Pont, D. \& Hérissé, C. 2004. Within-basin fish assemblage structure: the relative influence of habitat versus stream spatial position on local species richness. Canadian Journal Fisheries and Aquatic Science 61:93-102

HitT, N. P. \& ANGERMEIER, P. L. 2006. Effects of adjacent streams on local fish assemblage structure in Western Virginia. American Fisheries Society Symposium 48:75-86.

Hitt, N. P. \& ANGERMEIER, P. L. 2011. Fish community and bioassessment responses to stream network position. North American Benthological Society 30(1):296-309.

IBGE - Instituto Brasileiro de Geografia e Estatística. 1990. Mapa multirreferencial do Estado de Mato Grosso do Sul. Brasília, IBGE. 28p.

KINDT, R. \& COE, R. 2005. Tree diversity analysis. A manual and software for common statistical methods for ecological and biodiversity studies. Available at $<\mathrm{http}: / / \mathrm{www}$. worldagroforestry.org $>$. Accessed on 15 June 2005.

Krebs, C. J. 1999. Ecological methodology. Columbia, Addison Wesley Longman Inc. 620p.

Osborne, L. L. \& WiLEy, J. 1992. Influence of tributary spatial position on the structure of warmwater fish communities. Canadian Journal Fisheries and Aquatic Science 49:671-681.
Pavanelli, C. S. \& Caramaschi, E. P. 2003. Temporal and spatial distribution of the ichthyofauna in two streams of the Upper Rio Paraná Basin. Brazilian Archives of Biology and Technology 46(2):271-280.

Piedra-Cueva, I. 2009. Context and perspectives of the Plata Basin. Available at $<\mathrm{http}$ //tc.iaea.org/tcweb/abouttc/strategy/thematic/pdf/presentations/ RiverBasinManagement/ContextandPerspectivesofthePlataBasin.pdf>. Accessed on 11 May 2009.

Reis, R. E.; Kullander, S. O. \& Ferraris. C. J. 2003. Checklist of the freshwater fishes of South and Central America. Porto Alegre, EDIPUCRS. 729p.

Resende, E. K. \& SANTOS, D. C. 2002. Diagnóstico da pesca e aspectos da biologia reprodutiva dos peixes da bacia hidrográfica do rio Taquari, Mato Grosso do Sul, Brasil. Corumbá, EMBRAPA PANTANAL. 21p. (Embrapa Pantanal, Documentos, 25).

RotTa, M. A. 2003. Diagnóstico da piscicultura na Bacia do Alto Taquari - MS. Corumbá, EMBRAPA PANTANAL. 31p. (Boletim de Pesquisa e Desenvolvimento/Embrapa Pantanal).

Schaefer, J. F. \& Kerfoot, J. R. 2004. Fish assemblage dynamics in an adventitious stream: a landscape perspective. The American Midland Naturalist Journal 151:134-145.

Thomas, D. A. \& HaYes, D. B. 2006. A comparison of fish community composition of headwater and adventitious streams in a coldwater river system. Journal of Freshwater Ecology 21(2):265-275.

ThornBrugh, D. J. \& Gido, K. B. 2010. Influence of spatial positioning within stream networks on fish assemblage structure in the Kansas River basin, USA. Canadian Journal Fisheries and Aquatic Science 67:143-156.

Uieda, V. S.; Buzzato, P. \& Kikuchi, R. M. 1997. Partilha de recursos alimentares em peixes em um riacho de serra no sudeste do Brasil. Anais da Academia Brasileira de Ciências 69:243-252.

Willink, P. W.; Froehlich, O.; Machado-Allison, A.; Menezes, N.; Oyakawa, O.; Catella, A.; Chernoff, B.; Lima, F. C. T.; Toledo-Piza, M.; Ortega, H.; Zanata, A. M. \& Rarriga, R. 2000. Fishes of the Rios Negro, Negrinho, Taboco, Aquidauana, Taquari, and Miranda, Pantanal, Brasil: diversity, distribution, critical habitats and value. In: WILLINK, P. W.; Chernoff, B.; Alonso, L. E.; Montambault, J. R. \& Lourival, R. eds. A biological assessment of the aquatic ecosystems of the Pantanal, Mato Grosso do Sul, Brasil. RAP Bulletin of Biological Assessment 18. Conservation International, Washington, DC, p. 63-81. ZAR, J. H. 1974. Biostatistical analysis. London, Prentice-Hall. 620p.

ZuAnON, J.; Bockman, F. A. \& SAZIma, I. 2006. A remarkable sanddwelling fish assemblage from central Amazonia, with comments on the evolution of psammophily in South American freshwater fishes. Neotropical Ichthyology 4(1):107-118. 